\title{
PERBEDAAN HASIL BELAJAR KOGNITIF SISWA MELALUI PENGGUNAAN MEDIA AUDIO VISUAL DAN MEDIA PETA KONSEP PADA MATERI EKOSISTEM
}

\author{
Resta Agustiany ${ }^{1}$, Endang Hardi ${ }^{2}$, Nur Ilmiyati ${ }^{3}$ \\ 1,2,3Program Studi Pendidikan Biologi, Universitas Galuh, Jl. R.E. Martadinata No. 150, Ciamis, Indonesia \\ E-mail: restaagustiany@gmail.com
}

\begin{abstract}
Generally, the teaching of Biologi taking place in school has run very well due to the advanced and technological support which is increasingly developing. The use of various kinds of learning media, for example, can increase student motivation and interest in learning. Therefore, this study aims to find out whether or not there are significant differences between students' cognitive learning outcomes through the use of audio visual media and concept map media on ecosystem material. This online research is conducted through zoom application in April 2020 to 20 students of class $X$ IPA 1 and 20 students of class X IPA 2 who are selected purposively. The class X IPA 1 employs audio visual media and the class $X$ IPA 2 utilizes concept map media. The instrument used in this study is a set of written test containing the total number of 20 to analyze student cognitive learning outcomes. The results of hypothesis testing using the t-test at a $=5 \%$ level was obtained that value of $t$ - count is 8,91 and value of $t$-table $(0,975)$ is 2,02 . Because $t$ - count is higher than $t$ - table, thus, $\mathrm{Ho}$ is rejected and $\mathrm{Ha}$ is accepted. This means that there are differences in students' cognitive learning outcomes using audio visual media and concept map media on ecosystem material.
\end{abstract}

Keywords: Audio Visual Media, Concept Map Media, Cognitive Learning Outcomes

\begin{abstract}
ABSTRAK
Pengajaran biologi yang berlangsung di Sekolah pada umumnya sudah sangat baik terlebih dengan adanya penggunaan teknologi zaman sekarang yang semakin berkembang. Penggunaan berbagai macam teknologi sebagai media pembelajaran dapat meningkatkan motivasi dan minat belajar siswa. Oleh karena itu, penelitian ini bertujuan untuk mengetahui apakah ada perbedaan yang signifikan antara hasil belajar kognitif siswa melalui penggunaan media audio visual dan media peta konsep pada materi ekosistem. Penelitian ini dilakukan secara online melalui aplikasi zoom pada bulan April 2020 terhadap 20 siswa kelas X IPA 1 dan 20 siswa X IPA 2 di SMA Negeri 2 Ciamis yang dipilih menggunakan teknik purposive sampling. Kelas X IPA 1 menggunakan media audio visual dan kelas X IPA 2 menggunakan media peta konsep. Penelitian ini menggunakan metode quasi eksperimental dengan instrumen penelitian berupa tes tertulis sebanyak 20 nomor untuk menganalisis hasil belajar kognitif siswa. Adapun hasil pengujian hipotesis dengan menggunakan uji t pada taraf $a=5 \%$ diperoleh nilai t-hitung sebesar 8,91 dan $t$ - tabel $(0,975)$ sebesar 2,02, karena t- hitung > t- tabel, maka Ho ditolak dan Ha diterima. Artinya terdapat perbedaan hasil belajar kognitif siswa dengan menggunakan media audio visual dan media peta konsep pada materi ekosistem.
\end{abstract}

Kata kunci : Media Audio Visual, Media Peta Konsep, Hasil Belajar Kognitif

Cara sitasi: Agustiany, R., Hardi, E., \& IImiati, N. (2021). Perbedaan Hasil Belajar Kognitif Siswa melalui Penggunaan Media Audio Visual dan Media Peta Konsep pada Materi Ekosistem. J-KIP (Jurnal Keguruan dan IImu Pendidikan), 2 (1), 15-20. 


\section{PENDAHULUAN}

Berhasilnya tujuan pembelajaran dapat ditentukan oleh banyak faktor diantaranya faktor guru dalam melaksanakan proses belajar mengajar, karena guru secara tidak langsung dapat memberikan pengaruh yang besar bagi tercapainya tujuan pembelajaran serta dapat meningkatkan kemampuan kognitif siswa. Untuk mencapai keberhasilan dalam proses pembelajaran salah satunya yaitu dengan cara pemilihan media pembelajaran yang tepat dan tentunya sesuai dengan konsep mata pelajaran yang akan disampaikan oleh guru.

Menurut Arsyad (2013) mengemukakan pemakaian media pembelajaran dalam proses belajar mengajar dapat membangkitkan keinginan dan minat yang baru, membangkitkan motivasi dan rangsangan kegiatan belajar, dan bahkan membawa pengaruh-pengaruh psikologis terhadap siswa. Penggunaan media pembelajaran pada tahap orientasi pembelajaran akan sangat membantu keefektifan proses belajar mengajar dalam menyampaikan pesan dan isi pelajaran pada saat itu. Selain dapat membangkitkan motivasi dan minat siswa, media pembelajaran juga dapat membantu siswa dalam meningkatkan hasil belajar, dapat menyajikan data dengan menarik, memudahkan dalam penafsiran data serta dapat memadatkan informasi.

Menurut Utama, et al. (2014) mengungkapkan fungsi media dalam proses pembelajaran diantaranya, penyampaian pesan pembelajaran menjadi lebih terstandar serta dalam pembelajaran dapat lebih menarik dan lebih interaktif. Hal ini senada dengan pendapat Afifah, et al. (2020) yang menyatakan bahwa dalam kegiatan belajar sangat diperlukan interaksi positif yang terjadi antara guru dan peserta didik yang menyenangkan dan tidak membosankan. Selain itu media juga berfungsi dan berperan dalam mengatur hubungan yang efektif antara guru dan siswa dalam proses pembelajaran. Media pembelajaran yang memiliki karakteristik seperti tersebut adalah media audio visual dan media peta konsep.

Menurut Sanjaya (2010) "Media audio- visual adalah media yang mempunyai unsur suara dan unsur gambar yang dapat dilihat, misalnya seperti rekaman video, slide, suara dan sebagainya". Menurut Wati (2016) menyatakan bahwa media audio-visual memiliki beberapa kelebihan atau kegunaan, yaitu: "1) Memperjelas penyajian pesan agar tidak terlalu bersifat verbalistis (dalam bentuk kata-kata, tertulis atau lisan). 2) Mengatasi keterbatasan ruang, waktu dan daya indera". Penggunaan media audio visual ini juga dapat mengungkapkan suatu objek dan peristiwa yang sebenarnya. Dengan perencanaan yang baik dalam penggunaannya, media audio visual ini akan membuat proses komunikasi atau pembelajaran menjadi lebih efektif. Selain itu dapat memberikan pengalaman dasar bagi siswa ketika membaca maupun ketika berdiskusi dalam proses pembelajaran.

Menurut Buzan (2010) menyatakan media peta konsep dapat diartikan sebagai media yang berupa ilustrasi grafis yang digunakan untuk menghubungkan konsep-konsep ke dalam konsepkonsep lain pada kategori yang sama. Media peta konsep memiliki kelebihan bagi guru dan siswa, kelebihan tersebut bagi siswa diantarnya, pemetaan konsep merupakan pembelajaran bermakna yang akan meningkatkan pemahaman siswa dan daya ingat serta dapat meningkatkan kreativitas berfikir siswa dalam proses pembelajaran.

Penggunaan media audio visual ini juga dapat meningkatkan kemampuan berfikir siswa lebih kreatif dan inovatif serta dapat menarik siswa agar lebih termotivasi dan tidak mudah bosan dalam proses pembelajaran. Sedangkan penggunaan media peta konsep dapat membantu dalam menunjukan suatu konsep secara sistematis, yaitu dibentuk mulai dari inti permasalahan sampai pada bagian pendukung yang memiliki hubungan satu sama lain, sehingga dapat membentuk pengetahuan dan dapat mempermudah suatu pemahaman pada proses pembelajaran. Jadi, antara media audio visual dan media peta konsep masing-masing memiliki kelebihan satu sama lain. Akan tetapi, di antara kedua media tersebut juga terdapat perbedaannya. Seperti media audio visual yang memanfaatkan dua alat indera seperti indera penglihatan dan pendengaran, sedangkan media peta konsep hanya terfokus pada indera penglihatan saja. 
Berdasarkan latar belakang yang telah diuraikan, maka rumusan masalah dalam penelitian ini adalah adakah perbedaan hasil belajar kognitif siswa dengan menggunakan media audio visual dan media peta konsep pada materi ekosistem. Tujuan penelitian ini adalah untuk mengetahui perbedaan hasil belajar kognitif siswa dengan menggunakan media audio visual dan media peta konsep pada materi ekosistem.

\section{METODE PENELITIAN}

Dalam penelitian ini metode yang digunakan yaitu Eksperimen Semu (Quacy Eksperimental Design). Quacy Eksperimental Design ini adalah metode penelitian yang mamiliki kelompok kontrol, sehingga tidak dapat berfungsi sepenuhnya untuk mengontrol variable-variabel luar yang mempengaruhi pelaksanaan eksperimen. Metode ini dikembangkan untuk mengatasi kesulitan dalam menentukan kelompok kontrol dalam penelitian.

Desain yang digunakan dalam penelitian ini adalah Two-Group-Pretest Postest Design, dimana kelas eksperimen sebelum diberi perlakuan mendapatkan test awal (Pretest) dan setelah mendapat perlakuan diberikan tes akhir (Postest). Populasi dari penelitian ini adalah siswa kelas $X$ di SMA Negeri 2 Ciamis dengan sampelnya adalah kelas X IPA 1 dan X IPA 2.

Tabel 1. Desain Penelitian

\begin{tabular}{cccc}
\hline Kelompok & Pretest & Perlakuan & Post Test \\
\hline Eksperimen 1 & 0 & X1 & 0 \\
Eksperimen 2 & 0 & X2 & 0 \\
\hline
\end{tabular}

Keterangan:

$0 \quad$ : Pemberian Pretest dan Postest pada kelas eksperimen dan kontrol

$\mathrm{X}_{1} \quad$ : Perlakuan pada kelas eksperimen dengan pelaksanaan media audio visual

$\mathrm{X}_{2}$ : Pada kelas eksperimen dengan pelaksanaan media peta konsep (Sugiyono, 2016)

Instrumen yang digunakan dalam penelitian ini adalah tes objektif berupa pilihan ganda dengan lima pilihan (option) yaitu (A, B, C, D dan E) sebanyak 20 soal. Instrumen ini digunakan untuk mengukur aspek pengetahuan (C1), pemahaman (C2), aplikasi (C3), analisis (C4), sintesis (C5), evaluasi (C6). Tes ini diberikan sebelum dan sesudah pembelajaran menggunakan media pembelajaran audio visual dan media peta konsep. Hal ini untuk mengetahui peningkatan hasil belajar kognitif melalui nilai jawaban pada saat Pretest dan posttest atau yang disebut dengan NGain. Sebelum instrumen diuji cobakan akan melewati tahap expert judgemenet terlebih dahulu. Selanjutnya instrumen dilakukan pengujian syarat kelayakan tes, yaitu berupa uji validitas, reliabilitas, tingkat kesukaran dan daya pembeda.

\section{HASIL DAN PEMBAHASAN}

Data hasil penelitian diperoleh dari hasil Pretest dan posttest. Sedangkan yang dianalisis berupa nilai N-Gain. Data yang diperoleh dari hasil penelitian tercantum pada Tabel 2.

Tabel 2. Hasil Rata-rata Pretest, Posttest dan N-gain Menggunakan Media Audio Visual dan Media Peta Konsep

\begin{tabular}{cccc}
\hline Nilai / varian & Pretest & Postest & N-Gain \\
\hline Media Audio Visual & 58,25 & 85,75 & 66,15 \\
Media Peta Konsep & 54,0 & 76,0 & 46,40 \\
\hline
\end{tabular}

Berdasarkan Tabel 2 dapat diketahui bahwa rata-rata nilai Pretest dengan jumlah 20 siswa dari 35 siswa sebelum penggunaan media audio visual adalah sebesar 58,25 dan meningkat sebesar 27,5 
poin setelah penggunaan media audio visual menjadi 85,75 dengan nilai rata-rata N-Gain sebesar 66,15. Sedangkan rata-rata nilai Pretest dengan jumlah 20 siswa dari 34 siswa sebelum penggunaan media peta konsep adalah sebesar 54,0 dan meningkat sebesar 22,0 poin setelah penggunaan media peta konsep menjadi 76,0 dengan nilai rata-rata N-Gain sebesar 46,40. Maka dapat diketahui, bahwa nilai rata-rata siswa melalui penggunaan media audio visual lebih tinggi dibandingkan dengan penggunaan media peta konsep pada materi ekosistem.

Data hasil belajar kognitif siswa yang telah diperoleh kemudian dianalisis dengan uji normalitas, untuk mengetahui apakah data tersebut berdistribusi normal atau tidak. Rangkuman hasil uji normalitas dapat dilihat pada Tabel 3.

Tabel 3. Hasil Uji Normalitas

\begin{tabular}{ccc}
\hline Jenis varian & Media Audio Visual & Media Peta Konsep \\
\hline & 1,15 & 3,01 \\
\multirow{2}{*}{ Keterangan } & 7,81 & 7,82 \\
& Normal & Normal \\
\hline
\end{tabular}

Berdasarkan Tabel 3 diketahui bahwa distribusi data N-Gain setelah penggunaan media audio visual adalah normal karena nilai $\chi_{\text {hitung }}^{2} \chi_{\text {tabel }}^{2}=1,15<7,81$ dan distribusi data $\mathrm{N}$-Gain setelah penggunaan media peta konsep adalah normal karena nilai $\chi^{2}{ }_{\text {hitung }}^{<} \chi_{\text {tabel }}^{2}=$ $3,01<7,81$. Karena kedua data tersebut berdistribusi normal maka dilanjutkan dengan uji Homogenitas pada Tabel 4.

Tabel 4. Uji Homogenitas

Media Audio Visual \& Media Peta Konsep

1,66

$$
F_{\text {tabel }} 2,16
$$

Keterangan

Homogen

Berdasarkan Tabel 4 diketahui bahwa homogenitas data N-Gain setelah penggunaan media audio visual dan media peta konsep adalah homogen karena nilai $F_{\text {hitung }}<F_{\text {tabel }}=1,66<2,16$. Sehingga kedua data tersebut berdistribusi normal dan homogen maka dilanjutkan dengan uji hipotesis parametrik dengan uji thitung pada Tabel 5.

Tabel 5. Uji Hipotesis ( Uji Beda/uji t )

Media Audio Visual \& Media Peta Konsep

$\begin{array}{cc}\text { thitung } & 8,91 \\ \text { tabel}_{(0,975)} & 2,02\end{array}$

Keterangan

Hipotesis diterima

Berdasarkan Tabel 5 diketahui $t_{\text {hitung }}>t_{\text {tabel }}(0,975)=8,91>2,02$, sehingga dapat disimpulkan bahwa $\mathrm{H}_{\mathrm{o}}$ ditolak dan $\mathrm{H}_{\mathrm{a}}$ diterima yang berarti terdapat perbedaan hasil belajar kognitif siswa dengan menggunakan media audio visual dan media peta konsep.

Berdasarkan hasil penelitian menunjukan bahwa penerapan penggunaan media pembelajaran audio visual menyebabkan peningkatan hasil belajar yang lebih tinggi dibandingkan 
dengan media peta konsep terhadap hasil belajar kognitif siswa pada pelajaran Biologi materi ekosistem. Hal ini dapat diketahui dari nilai rata-rata (NGain) hasil belajar siswa yang menggunakan media audio visual lebih tinggi dibandingkan hasil belajar siswa yang menggunakan media peta konsep.

Hal tersebut juga sesuai dengan penelitian yang dilakukan Prabowo (2017) berkaitan dengan perbedaan hasil belajar siswa menggunakan media audio visual dan media peta konsep, dan hasilnya diketahui bahwa hasil belajar dengan menggunakan media audio visual memberikan pengaruh lebih baik dibandingkan dengan hasil belajar menggunakan media peta konsep.

\section{KESIMPULAN}

Berdasarkan data hasil analisis dan pembahasan pada penelitian ini, maka disimpulkan bahwa terdapat perbedaan hasil belajar kognitif siswa dengan menggunakan media audio visual dan media peta konsep. Hal ini diketahui dari hasil belajar dengan menggunakan media audio visual memberikan pengaruh lebih baik dibandingkan dengan hasil belajar menggunakan media peta konsep pada materi ekosistem.

\section{REKOMENDASI}

Penelitian menggunakan audio visual secara daring harus memastikan terlebih dahulu perangkat pembelajaran yang digunakan oleh siswa berjalan dengan baik agar proses pembelajaran berjalan sebagaimana semestinya.

\section{UCAPAN TERIMA KASIH}

Peneliti mengucapkan terima kasih kepada kepala SMA Negeri 2 Ciamis yang telah mengizinkan penelitian ini dilaksanakan.

\section{DAFTAR PUSTAKA}

Afifah, A, N., Ilmiyati, N., \& Toto. (2020). Pengaruh Model Project Based Learning (PJBL) dengan Pendekatan STEM terhadap Penguasaan Konsep dan Keterampilan Berpikir Kritis Siswa. JKIP (Jurnal Keguruan dan IImu Pendidikan), 1(2), 33-40.

Arsyad. (2013). Media Pembelajaran. Jakarta: PT Raja Grafindo.

Buzan, T. (2010). Memahami Peta Pikiran: The Mind Map Book. Jakarta: Kencana Prenada Media Group.

Sanjaya, W. (2010). Strategi Pembelajaran Berorientasi Standar Proses Pendidikan. Jakarta: Kencana.

Sugiyono. (2016). Metode Penelitian Kuantitatif, Kualitatif dan R\&D. Bandung: PT Alfabet.

Utama, C., Kentjananingsih, S., \& Rahayu, Y. S. (2014).Penerapan Media Pembelajaran Biologi SMA dengan Menggunakan Model Direct Instruction. Jurnal Pena Sains. 1(1), $29-40$.

Prabowo, P. (2017). Perbedaan Hasil Belajar Biologi Menggunakan Media Peta Konsep dan Media Audio Visual. Jurnal Penelitian, Pemikiran dan Pengabdian, 5 (1), 67-74.

Wati, E, R. (2016). Ragam Media Pembelajaran. Yogyakarta: Kata Pena 
